\title{
A comparison of the effects of platelet-rich plasma and demineralized bone matrix on critical bone defects: An experimental study on rats
}

\author{
Egemen Turhan, M.D., ${ }^{1}$ Mustafa Kemal Akça, M.D., ${ }^{2}$ Ahmet Bayar, M.D., ${ }^{3}$ \\ Murat Songür, M.D., ${ }^{3}$ Selçuk Keser, M.D., ${ }^{3}$ Mahmut Nedim Doral, M.D. ${ }^{1}$
}

\begin{abstract}
'Department of Orthopedics and Traumatology, Hacettepe University Faculty of Medicine, Ankara-Turkey
2Department of Orthopedics and Traumatology, Bandırma Government Hospital, Balıkesir-Turkey

${ }^{3}$ Department of Orthopedics and Traumatology, Bülent Ecevit Faculty of Medicine, Zonguldak-Turkey
\end{abstract}

\begin{abstract}
BACKGROUND: Delayed union of fractured bone is one of the main problems of orthopedics and traumatology practice. It was hypothesized that the beneficial effects of allogeneic platelet-rich plasma (PRP) would be valuable in the treatment of segmental bone defects. This study is a comparison of the effects of demineralized bone matrix (DBM) and PRP in a segmental bone defect model.

METHODS: Total of 48 Wistar albino rats were separated into 4 groups. Segmental bone defect was created at right radius diaphysis in all specimens using dorsal approach. Four additional rats were used as PRP source. Intracardiac blood was withdrawn before the operation for preparation of allogeneic PRP. Group I $(n=12)$ served as control group and defects were left untreated. Group 2 ( $n=12$ ), was PRP group, and received grafting with PRP. Group $3(n=12)$ was PRP+DBM combination group, and was treated with grafting and mixture of DBM and PRP. In Group $4(n=12)$, defect area was grafted with DBM only. At the end of $10^{\text {th }}$ week, rats were sacrificed, forearms were dissected, and defect areas were examined with radiological and histopathological parameters.
\end{abstract}

RESULTS: Radiological evaluation revealed that ossification was best in PRP group, followed by DBM group. According to results of histopathological studies, union quality was better than control group in all treatment groups (Groups 2, 3, and 4), and was best in PRP group $(p<0.05)$. Results were also better in PRP group when examined in terms of cortex development and remodeling $(p<0.05)$. When examined in terms of new osteogenesis, results were comparable in Groups 2, 3, and 4, but all were better than control group.

CONCLUSION: It was concluded that PRP and DBM have comparable effect on recovery of defective bones, but there is no synergistic effect when used together. We believe that PRP can be a cost-effective, readily available alternative to DBM with minimal morbidity.

Keywords: DBM; PRP; segmental bone defect.

\section{INTRODUCTION}

Bone defects caused by infection, tumor, high-energy trauma, metabolic disease or massive osteolysis due to prosthesis loosening still remain a major clinical concern. Unfortunately,

Address for correspondence: Egemen Turhan, M.D. Hacettepe Üniversitesi Tıp Fakültesi, Ortopedi ve Travmatoloji Anabilim Dalı, 06100 Ankara, Turkey

Tel: +90 312 - 3051209 E-mail: dregementurhan@yahoo.com

Qucik Response Code Ulus Travma Acil Cerrahi Derg

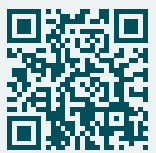

2017;23(2):91-99

doi: $10.5505 /$ tjtes.2016.68249

Copyright 2017

TJTES the self-repair capacity of the critically defected bone is extremely limited and this condition generally requires bone grafting for mechanical and biological enhancement. Osteoinductivity, osteoconductivity, and osteogenesis are desired properties of an optimal bone graft substitute. Autogenous bone grafts ( $A B G)$ have these features and are currently considered the "gold standard". ${ }^{[1-3]}$ ABG also have advantages of being easy to harvest, economical, and non-immune. However, use of $A B G$ has some limitations such as donor side morbidity, limited reserve, and weak mechanical properties. Allografts or xenografts have unique osteoconductive properties and rarely cause disease transmission. As a result of these limitations, synthetic bone graft substitutes are being investigated. Osteoconductive agents such as ceramics, polymers, trabecular metals, and bioactive glass have been employed to provide mechanical support for vascular and bone ingrowth. ${ }^{[4,5]}$ Osteoinductive growth factors, autogenic bone 
marrow and mesenchymal root cells promote osteogenesis while demineralized bone matrix (DBM) and platelet-rich plasma (PRP) induce formation of progenitor cells from surrounding tissues. However, each of these substitutes has its own significant limitations and none of them meets full expectations to serve as bone substitute in instance of bone defect. $^{[6]}$

Both PRP and DBM are osteoinductive substitutes that have been proven to yield satisfactory results for fracture healing. ${ }^{[1-3,7-14]} A$ number of growth and differentiation factors are liberated, including platelet-derived growth factor (PDGF), vascular endothelial growth factor (VEGF), transforming growth factor- $\beta$ I (TGF- $\beta I$ ), insulin-like growth factor-I (IGF-I), hepatocyte growth factor, platelet factor-4, fibroblast growth factor (FGF), trombospondin-I, osteonectin, and fibronectin via activation of platelets. ${ }^{[15]}$ These factors play an imperative role in intracellular signaling pathways, initiating the production of ultimate proteins essential for cellular proliferation, matrix formation, osteoid production, and the collagen synthesis involved in fracture healing. ${ }^{[16-22]}$ DBM is an organic collagen matrix that includes various types of bone morphogenetic proteins (BMP), which are responsible for its osteoinductive properties. This BMP-rich matrix modulates the differentiation of progenitor cells into osteoprogenitor cells, which are responsible for bone and cartilage formation. ${ }^{[23,24]}$ PRP can be prepared easily with 2-step centrifugation of autogenous blood, and DBM can be obtained commercially.

Positive impacts of PRP and DBM alone and in combination with other substitutes are well documented, but no assessment has been made as yet of a combination of PRP and DBM on healing of long bone defects. Based on these findings, the present study evaluated the impact of individual and combined applications of PRP and DBM on fracture healing of critical bone defects. It was hypothesized that allogeneic PRP would have beneficial effect on treatment of segmental bone defects, comparable to DBM. Possibility of agonistic or additive osteoinductive effects of DBM and PRP combination was also investigated.

\section{MATERIALS AND METHODS}

\section{Animals and Surgical Procedure}

This experimental study was conducted at Bülent Ecevit University (Zonguldak, Turkey) animal research laboratories, after receiving the approval of the ethics committee for animal research (1564-2599-20 I I/2 I). Forty-eight, 9-month-old, male, inbred Wistar albino rats with an average weight of $350 \mathrm{~g}$ were used in this study. Twelve rats of similar age and weight were used for PRP preparation. Prior to surgical creation of bone defects, all animals were allowed to acclimate to the laboratory environment for a period of 10 days. All rats were kept in plastic cages with access to food and water ad libidum and screened for common disease. Rats were maintained at $22^{\circ} \mathrm{C} \pm-2^{\circ} \mathrm{C}$ environmental temperature in 12 hours light and 12 hours darkness cycle. None of the rats had been subjected to any experiments prior to this study. The rats were randomly divided into 4 groups:
I. Control group $(n=\mid 2)$
2. PRP group $(n=12)$
3. $P R P+D B M$ group $(n=12)$
4. DBM group $(n=\mid 2)$

Twenty-four hour before surgical procedure, the animals were fasted. A single dose of lespor (cephazoline sodium, 20 $\mathrm{mg} / \mathrm{kg}$; Ibrahim Ethem Ulugay İlaç Sanayi Türk A.Ş., İstanbul, Turkey) was administered to all animals preoperatively. All rats were anesthetized with $50 \mathrm{mg} / \mathrm{kg}$ of ketamine hydrochloride (Ketalar; Pfizer Inc., NY, NY, USA), injected intraperitoneally, prior to surgery. ${ }^{[25]}$ Anesthesia was monitored and maintained by a veterinarian during all phases of surgical procedure. Rats were placed in right decubitus and left forearm was shaved. Bone defect of approximately $10-\mathrm{mm}$ (twice the radius of radii) was created in midshaft of the radius with a sharp rib bone knife. Osteotomy site was then irrigated with $0.9 \%$ saline, but no attempt was made to resect the periosteum around osteotomy site as this had been retracted with the overlying muscles. Osteotomy site was treated following the protocol for each group. As only the radius had been osteotomized, no fixation was employed, and the animals were able to use both extremities effectively. ${ }^{[26-28]}$ Bone defects in Group 3 (DBM) and Group 4 (DBM+PRP) were filled with approximately $0.3 \mathrm{cc}$ injectable DBM (Ultra DBM Matrix; TissueNet, Inc., Orlando, FL, USA). Immediately after surgery, while rats were still under anesthesia, roentgenograms of the limbs were taken. Fifteen $\mathrm{mg} / \mathrm{kg}$ of tramadol (Ultramex, Adeka İlaç Kimyasal Ürünler Sanayi ve Ticaret A.Ş., Istanbul, Turkey) was used for postoperative analgesia. Rats were then put into separate cages with no restriction of activities. Parizi et al. proposed that if PRP was injected intraoperatively during the surgical operation, inflammatory agents could destroy the injected PRP and render it potentially ineffective in later stages of healing. [29] Therefore I mL of allogeneic PRP was injected percutaneously into bone defects in Group 2 and Group 3 on postoperative third day.

\section{Allogeneic PRP Preparation}

Four rats per 12 experimental animals ( 12 exsanguination animals total) were anesthetized with $50 \mathrm{mg} / \mathrm{kg}$ of ketamine hydrochloride (Ketalar; Pfizer Inc., NY, NY, USA), injected intraperitoneally, prior to blood collection via intracardiac aspiration after sternotomy.

Sterile disposable monovette system (blood collection tubes) and compatible centrifuge machine (Nüve NF 1000R, Nüve Sanayi Malzemeleri Imalat ve Ticaret A.Ş., Ankara, Turkey) was used to prepare PRP. Blood was transferred into blue 
capped monovette containing $3.2 \%$ sodium citrate $(0.5 \mathrm{~mL})$, approximately 30 minutes before injection. Monovette was centrifuged at $1800 \mathrm{rpm}$ for 10 minutes. ${ }^{\left[16,{ }^{19]}\right]}$ After first centrifugation, 2 layers were clearly visible in monovette. Upper yellow layer consisted of platelet-rich and platelet-poor plasma, while lower red layer consisted of erythrocytes and leukocytes, as has previously been documented. ${ }^{[30]}$ Lower red layer has been reported to be rich in platelets that recently entered the circulation. ${ }^{[3,32]}$ Total plasma consisting of complete upper yellow layer and top I to $2 \mathrm{~mm}$ of lower red layer was transferred to sterile monovette. After second centrifugation at $4000 \mathrm{rpm}$ for 7 minutes, approximately 0.7 $\mathrm{mm}$ at the bottom of the monovette was platelet-rich plasma and upper portion was mostly platelet-poor plasma. ${ }^{[30]} \mathrm{Su}$ pernatant platelet-poor plasma was collected and removed by pipette. Remaining platelet-rich plasma was then carefully transferred into application injector.

\section{Radiological Analysis}

After 10 weeks of healing, rats were sacrificed and upper extremities were removed from the corpus in order to obtain optimal anterior-posterior X-ray images. Two orthopedic surgeons who were blinded to group assignments but informed about evaluation method performed radiological assessments. These 2 surgeons were not involved in the present study. Results were scored using the grading scale described by Cook et al. (Table I). ${ }^{[33]}$

\section{Histological and Histomorphometrical Analysis}

Whole specimens were initially fixed in 10\% formaldehyde for 2 weeks. During subsequent 2 weeks, samples were placed in 10\% ethylenediaminetetraacetic acid solution for decalcification process. Samples were than embedded in paraffin blocks and $5 \mu \mathrm{m}$-thick sections were cut through long axis from fractured zone and stained with hematoxylin and eosin for routine light microscope analysis. ${ }^{[34]}$ Pathologist who was blinded to groups and experimental procedure evaluated the specimens with 14-point histological grading scale described by Salkeld et al. (Table 2) to determine quali- ty of union, appearance and quality of cortical and cancellous bone remodeling, and degree of bone graft incorporation and remodeling. ${ }^{[35]}$

\section{Statistical Analysis}

Statistical analysis was performed in the Department of Biostatistics at Bülent Ecevit University Faculty of Medicine using SPSS software, version 18.0 (Customer number: II4094, 2012; SPSS, Inc., Chicago, IL, USA). Descriptive statistics included median (minimum and maximum) values. KruskalWallis analysis of variance was used to compare the groups in terms of radiological and histopathological results. After performing Kruskal-Wallis analysis of variance, Wilcoxon test was performed with Bonferroni correction for paired comparison of groups. Results were expressed within a $95 \%$ confidence interval. Significance was defined as $p<0.05$.

\section{RESULTS}

One rat from control group did not wake from anesthesia, so total of 47 completed the experiment without major wound or other complication. These 47 rats were sacrificed for radiological and histological assessments.

\section{Radiological Findings}

Table 3 summarizes radiological evaluation results. In radiological assessment of healing, there were significant differences between control group and PRP group, and PRP group and PRP+DBM combination group, in favor of PRP group $(p=0.007)$. There was no significant difference between control group and PRP+DBM combination group $(P=0.354)$. No obvious cortical bridging was denoted in either control or PRP+DBM groups. There was significant difference between control group and DBM group $(\mathrm{p}<0.00 \mathrm{l})$. There was also significant difference between DBM group and PRP+DBM combination group. PRP group achieved higher scores in radiological assessment. Radiological data also indicated that control group and PRP/DBM combination group displayed similar level of radiological healing (Figure la-d).

Table I. Radiographic grading scale for the degree of healing (Cook et al. ${ }^{[33]}$ )

\section{Description}

No change from immediate postoperative appearance

A slight increase in radiodensity distinguishable from the graft

Recognizable increase in radiodensity, bridging of one cortex with new-bone formation to the graft

Bridging of at least one cortex with material of nonuniform radiodensity, early incorporation of the graft suggested by

obscurity of graft borders

Defect bridged on both medial and lateral sides with bone of uniform radiodensity, cut ends of the cortex still visible, graft and new bone not easy to differentiate

Same as grade 3, with at least one of four cortices obscured by new bone 
Table 2. Histological grading scale for the degree of healing (Salkeld et al. ${ }^{[35])}$

\begin{tabular}{|c|c|c|}
\hline Criteria & Description & Score \\
\hline \multirow[t]{5}{*}{ Quality of union } & No sign of fibrous or other union & 0 \\
\hline & Fibrous union & 1 \\
\hline & Fibrocartilaginous union or cartilage union & 2 \\
\hline & Mineralizing cartilage and bone union & 3 \\
\hline & Bone union & 4 \\
\hline Cortex development and & No cortex formed & 0 \\
\hline \multirow[t]{4}{*}{ remodeling } & Formation of new bone along exterior borders & 1 \\
\hline & Recognizable formation of both the outer cortex border and the medullary space & 2 \\
\hline & Cortices formed but incomplete bridging & 3 \\
\hline & Complete formation of cortices with bridging of defect & 4 \\
\hline \multicolumn{3}{|l|}{ Bone-graft incorporation and } \\
\hline \multirow{5}{*}{ No new bone, all or most of graft Visible } & Graft material present, no incorporation, and no new-bone formation & 0 \\
\hline & Graft present, some incorporation with new bone formation, and small & \\
\hline & amount of new bone & I \\
\hline & Graft present, some incorporation with new bone formation, and moderate & \\
\hline & amount of new bone & 2 \\
\hline \multirow[t]{6}{*}{ Decreasing graft, increasing new bone } & Graft present, some incorporation with new-bone formation continuous & \\
\hline & with host bone, and early remodeling changes in new bone & 3 \\
\hline & Decreased amount of graft (compared with grade 3), good graft & \\
\hline & incorporation, and ample new bone & 4 \\
\hline & Less amount of graft still visible (compared with grade 4), good incorporation & \\
\hline & of graft and new bone with host and ample new bone & 5 \\
\hline No graft visible, extensive new bone & $\begin{array}{l}\text { Difficult to differentiate graft from new bone, excellent incorporation, and } \\
\text { advanced remodeling of new bone with graft and host }\end{array}$ & 6 \\
\hline
\end{tabular}

\section{Histopathological Findings}

Histopathological evaluation was based on the following parameters: I) quality of union, 2) cortical development and remodeling, and 3) new bone formation.
There was a significant difference between control group and PRP group in terms of quality of union $(p<0.001)$. Endochondral ossification in defect site was most clearly seen in PRP group. There was significant difference between control group
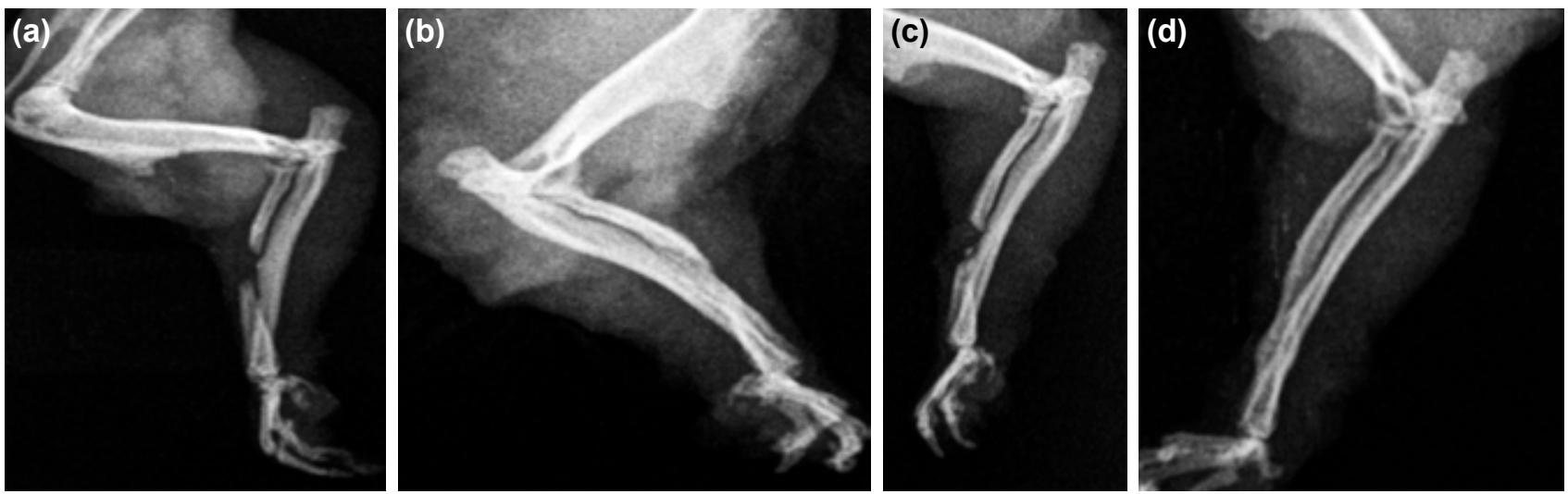

Figure 1. Radiological samples of the groups (a) Control group - No change from immediate postoperative appearance. (b) PRP group - Defect bridged by uniform new bone, cut ends of cortex no longer distinguishable. (c) PRP/DBM group - Recognizable increase in radiodensity, bridging of cortex with new-bone formation to the graft. (d) DBM group - Defect bridged on both medial and lateral sides with bone of uniform radiodensity, cut end of distal cortex still visible. 
Table 3. Radiological assessment scoring of the experiment groups according to Cook criteria

\begin{tabular}{lcccc}
\hline Cook Score & $\begin{array}{c}\text { Group I } \\
\text { Control }(\mathbf{n}=11)\end{array}$ & $\begin{array}{c}\text { Group 2 } \\
\text { PRP }(\mathbf{n}=12)\end{array}$ & $\begin{array}{c}\text { Group 3 } \\
\text { PRP+DBM }(\mathbf{n}=12)\end{array}$ & $\begin{array}{c}\text { Group 4 } \\
\text { DBM }(\mathbf{n}=12)\end{array}$ \\
\hline Minimum & 0 & 2 & 2 & 2 \\
Maximum & 4 & 6 & 5 & 6 \\
Median & 2 & 4 & 2 & 3 \\
\hline
\end{tabular}

PRP: Platelet-rich plasma; DBM: Demineralized bone matrix.

Table 4. Histopathological evaluation results according to Salkeld scoring method

\begin{tabular}{|c|c|c|c|c|c|}
\hline Criteria & & Control & PRP & PRP+DBM & DBM \\
\hline \multirow[t]{3}{*}{ Quality of union } & Median & $\mathrm{I}$ & 3 & 3 & 2 \\
\hline & Minimum & 1 & 2 & 2 & 2 \\
\hline & Maximum & 2 & 4 & 3 & 3 \\
\hline \multirow[t]{3}{*}{ Cortex development and remodeling } & Median & I & 2 & I & 2.5 \\
\hline & Minimum & 0 & I & 0 & 0 \\
\hline & Maximum & 2 & 4 & 2 & 4 \\
\hline \multirow[t]{3}{*}{ New bone formation } & Median & 1 & 2 & 2 & 2 \\
\hline & Minimum & 1 & 1 & I & 1 \\
\hline & Maximum & 2 & 4 & 3 & 3 \\
\hline
\end{tabular}

PRP: Platelet-rich plasma; DBM: Demineralized bone matrix.

and PRP+DBM combination group, while no difference was found between PRP group and DBM group $(p=768)$. There was significant difference between control group and DBM group $(p<0.001)$ : fibrous union was greatest in control group. There was no significant difference between PRP group and $P R P+D B M$ combination group $(p=0.456)$. Although Salkeld scores were slightly higher in PRP+DBM combination group, there was no statistically significant difference between combination group and DBM group $(p=0.874)$.

Significant difference was found between PRP group and $\mathrm{PRP}+\mathrm{DBM}$ group in terms of cortical development and remodeling that favored PRP group $(\mathrm{p}<0.00 \mathrm{I})$. There was also statistically significant difference between the PRP+DBM combination group and DBM group, with greater healing seen in DBM group $(p=0.010)$. In addition, there was significant difference found between control group and PRP group $(p<0.00 \mathrm{I})$. There was no significant difference between control group and PRP+DBM group $(p=0.624)$. Cortex development remodeling was significantly superior in DBM group than control group $(p<0.001)$. No significant difference was determined between PRP group and DBM group $(p=0.323)$.

In terms of new bone formation, rats in control group had significantly lower scores compared with PRP, PRP+DBM combination, and DBM groups $(p=0.334)$, and there was no significant difference between the experiment groups $(p=0.063)$. Summary of histopathological findings is provided in Table 4. Significant microscopic findings of the groups are provided in Figure $2 \mathrm{a}-\mathrm{d}$.

\section{DISCUSSION}

Segmental bone defects continue to be a major problem in the practice of orthopedics and traumatology. There is still no universally accepted treatment standard for this problem. The current therapies are disputable in terms of morbidity and cost/benefit ratio, and it is obvious that new approaches are required. The present study evaluated effects of PRP application to healing of segmental bone defects, what we consider to be a new approach in the treatment of segmental bone defects.

This research demonstrated that PRP is as efficient as DBM based on radiological and histopathological evidence of healing in segmental bone defects; however, same effects were not observed with the combined use of PRP and DBM.

For many years, researchers working with bone tissue have been investigating methods and bone grafts that would accelerate fracture healing and promote rapid recovery of bone defects or that could be used in the reconstruction of larger defects to achieve union and filling of the defect with fewer complications. Although there was success in these studies, 

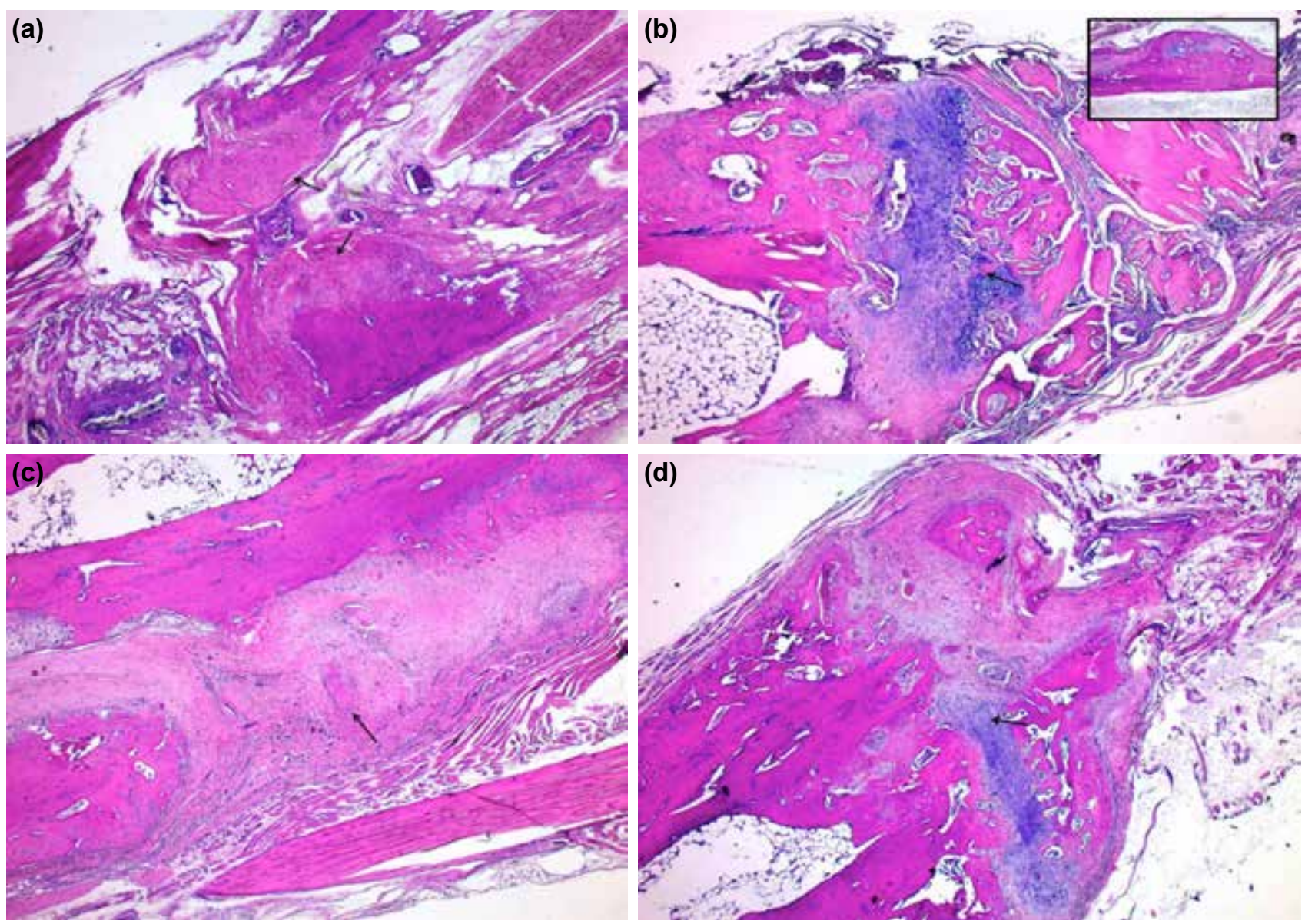

Figure 2. (a) Control group - Arrow indicates bone defect region filled with fibrous tissue (H\&E; original magnification x40). (b) PRP group - The defect site in PRP group filled with cartilaginous tissue (black arrow) (H\&E; original magnification x40). High power view of the inset reveals periosteal new bone, bridging, and cortex development (H\&E; original magnification x100). (c) PRP/DBM group - The osteotomy site filled with fibrocartilaginous tissue without cortex formation (black arrow) (H\&E; original magnification x40). (d) DBM group - The osteotomy site filled with cartilaginous tissue with minimal new bone formation (black arrow) (H\&E; original magnification x40).

these methods are not commonly used in clinical practice. ${ }^{[1,2,4-}$ 6] It was realized that bone metabolism is regulated through various chemical and metabolic pathways, and that certain peptides (growth factors) are released from platelets, macrophages, and fibroblasts during the union of fractures. These proteins are known to organize delicate processes such as proliferation, differentiation, migration, and resorption in the healing of fractures. Studies have focused on the production of these growth factors with recent advances in recombinant gene technology. The main focus of these studies has been BMPs from the TGF family, and TGF- $\beta$, PDGF, VEGF, FGF, and IGF have been shown to have favorable effects on bone healing. Experimental studies have demonstrated the favorable effects of these molecules on bone healing; however, these substances have not been introduced into clinical practice due to high costs of recombinant gene technology. ${ }^{[36-38]}$

Many growth factors including PDGF, VEGF, TGF $\beta \mathrm{I}-2$, and FGF are deposited in the granules of circulating platelets, and these substances are released in response to various stimulations. ${ }^{[39]}$ In light of these data, the present study aimed to extract these growth factors by centrifugation of allogeneic venous blood in order to reduce the costs. PRP suspension prepared from venous blood contains many growth factors as well as fibrinogen, and application to fracture site allows direct activity to occur.

Experimental studies with PRP are required before the introduction of PRP into clinical practice due to the fact that available studies either lack control groups or they are insufficient. Among these limited studies, Marx et al. compared autologous bone graft alone with autologous bone graft plus PRP application and noted an increase in bone formation and bone density, which they attributed to PDGF and TGF- $\beta .{ }^{[18,40-}$ ${ }^{42]}$ Anitua et al. injected PRP into empty cavity after tooth extraction and reported an increase in both epithelialization and bone density. ${ }^{\left[{ }^{9]}\right.}$ Aghaloo and Butterfield study of bone grafts and PRP application failed to show superiority of PRP; however, there are also studies showing accelerated advancement of bone tissue when PRP is used with the grafts used in dentistry for osteointegration, and there are also reports on successful outcomes in maxillary arthroplasty. ${ }^{[8,32,43]}$ 
PRP has been used together with autograft and hydroxyapatite in patients undergoing lumbar spinal fusion, and both favorable and unfavorable outcomes have been reported. ${ }^{[44,45]}$ Siebrecht et al. showed that PRP increased tissue ingrowth and ossification inside porous hydroxyapatite, and they also reported increased tensile strength and callus of Achilles tendon of rats after PRP application. ${ }^{[42]}$ Use of plasma-rich plasma was recommended in arthroscopic surgery after demonstration of favorable effects on ligaments. ${ }^{[36]}$

Nagata et al. compared autograft and autograft-PRP combination after creating critically large calvarial bone defect in rabbits, and they noted significantly faster ossification at 4 weeks in the autograft-PRP group; however, outcomes at 12 weeks were similar in the 2 groups. ${ }^{[45]}$ Cheng et al. evaluated outcomes of PRP, autograft, and PRP-bone marrow-derived stromal cell mixture on critically large calvarial bone defect in rabbits, and reported minimum repair in PRP group and significantly higher new bone formation in bone marrow-derived stromal cell plus PRP group. ${ }^{[46]}$

Gumieiro et al. compared PRP and control groups using monocortical defect model in irradiated rat tibia and reported statistically significant outcomes in terms of ossification. ${ }^{[4]}$

In the present study we also questioned the possibility of agonistic effects of DBM and PRP on fracture healing. DBM was selected for its osteoinductive effects based on BMPs, while PRP lacks these proteins. Our study revealed that both PRP and DBM had favorable effects on fracture healing when applied separately, but combination of these methods did not provide additional benefits. This finding was also supported by a study conducted by Ranly et al. on athymic rats in which DBM embedded in gastrocnemius muscle was combined with PRP that was and was not activated by thrombin, and ossification was evaluated at days 14, 28, and 56 after application. ${ }^{[48]}$ Combination of PRP and DBM did not display any additional benefits to condrogenesis over DBM alone at day 14; however, the combination was associated with induction of osteogenesis and higher production of new bone islets and new bone formation at days 28 and 56. On the other hand, thrombin-activated PRP had inhibitor effect on DBM and inhibited both condrogenesis and osteogenesis. In our study, PRP was kept in citrated tubes after preparation and activated with citrate. In a study conducted by BoHan et al., combination of DBM and PRP was implanted in muscle tissue to examine ectopic bone formation within the connective tissue. PRP produces different responses in different tissue. Their study evaluated the fracture healing process when PRP was used alone and in combination with DBM.They concluded that PRP significantly increased in vivo DBM osteoinductivity only when used without thrombin activation. ${ }^{[49]}$ In the present study we demonstrated that citrate-activated PRP can also inhibit osteoinductive effect of DBM.

In another study by Ranly et al. in immunosuppressed rats, implants prepared with DBM and various doses of PRP were inserted into leg muscles of rats, and they evaluated osteoinduction, new bone and cartilage formation, and if PRP and implanted DBM played a modulator role in osteoinduction by dissecting the tissue at days 14,28 , and 56. ${ }^{[50]}$ The examination at day 14 showed that amount of cartilage decreased with increasing PRP doses, and in addition, dissection performed at days 28 and 56 showed that PRP delayed new bone formation and resorption of the graft in a dose-dependent manner. In their study, both PRP and DBM were found to be effective in the healing of fractures; however, combined use of these substances did not have additional benefit over single use. This study evaluated new bone formation inside muscle tissue and not new bone formation in the fracture line. PRP results are different in each model, and exogenous PRP applied to the fracture line may accelerate the healing of fracture together with other osteogenic proteins. PRP applied in the present study was released from implants in the early inflammatory phase of osteoinduction in the soft tissue, whereas later application of PRP to the fracture site induces PRP production from the osteoblasts as if it were a paracrine factor. Due to technical difficulties the dose of PRP was not adjusted in our study, and the response to the healing of segmental defect was evaluated after application of PRP to the bone defect

One of the limitations of our study was that dose standardization for PRP and DBM was not possible due to technical drawbacks. This study evaluated 2 phases, namely the initial and final phases, and interim phases were not evaluated. In addition, biomechanical studies regarded as optimal for evaluating the healing of fractures were not appropriate in rat bone defect model and therefore could not be performed. In this study, withdrawal of autologous blood from each rat for PRP preparation was not feasible because of the risk of sample loss due to blood collection, and therefore, PRP was prepared from blood withdrawn from 4 other rats though intracardiac route at the beginning of the study and allogeneic PRP was used. Burhoe and Moore demonstrated that there are subgroups of blood in rats, although there is no blood type; however, this was not taken into consideration due to the fact that these subgroups do not exhibit immunogenicity against each other. ${ }^{[51,52]}$

\section{Conclusion}

Radiological and histological assessment in this study revealed similar results for PRP and DBM, and the combination of these 2 did not provide additional benefits. As an autologous product, absence of any risk for the transmission of infection, absence of allergic reactions, easy preparation in the operating room, and lack of additional costs can be regarded as advantages of PRP over commercial DBM products.

The present study was an experimental animal study, and our literature search revealed that this was the first study to eval- 
uate use of PRP and DBM combination in bone tissue. PRP is currently used in muscle-tendon injuries and similar studies can guide future prospects for the use of PRP to accelerate healing in segmental bone defects.

This research demonstrated that PRP is as efficient as DBM in the treatment of segmental bone defects, and similar results in in vivo tests and biomechanical studies may lead to the introduction of PRP therapy to clinical practice in the treatment of segmental bone defects.

\section{Conflict of interest: None declared.}

\section{REFERENCES}

1. Finkemeier CG. Bone-grafting and bone-graft substitutes. J Bone Joint Surg Am 2002;84:454-64. Crossree

2. Greenwald AS, Boden SD, Goldberg VM, Khan Y, Laurencin CT, Rosier RN. Bone-graft substitutes: facts, fictions, and applications. J Bone Joint Surg Am 2001;83(Suppl 2 Pt 2):98-103. Crossre]

3. Parikh SN. Bone graft substitutes in modern orthopedics. Orthopedics 2002;25:1301-11.

4. Penteado LA, Colombo CE, Penteado RA, Assis AO, Gurgel BC. Evaluation of bioactive glass and platelet-rich plasma for bone healing in rabbit calvarial defects. J Oral Sci 2013;55:225-32. Crossre,

5. Hollinger JO, Brekke J, Gruskin E, Lee D. Role of bone substitutes. Clin Orthop Relat Res 1996;324:55-65. Crossret

6. Simsek A, Çakmak G, Cila E. Kemik Greftleri ve Kemik Greftlerinin Yerini Tutabilecek Maddeler TOTBİD (Türk Ortopedi ve Travmatoloji Birligi Dernegi) Dergisi 2004;3:3-4.

7. Thalgott JS, Giuffre JM, Klezl Z, Timlin M. Anterior lumbar interbody fusion with titanium mesh cages, coralline hydroxyapatite, and demineralized bone matrix as part of a circumferential fusion. Spine J 2002;2:63-9.

8. Aghaloo TL, Moy PK, Freymiller EG. Investigation of platelet-rich plasma in rabbit cranial defects: A pilot study. J Oral Maxillofac Surg 2002;60:1176-81. Crossre.

9. Parizi AM, Oryan A, Shafiei-Sarvestani Z, Bigham AS. Human platelet rich plasma plus Persian Gulf coral effects on experimental bone healing in rabbit model: radiological, histological, macroscopical and biomechanical evaluation. J Mater Sci Mater Med 2012;23:473-83. Crossre

10. Kassolis JD, Rosen PS, Reynolds MA. Alveolar ridge and sinus augmentation utilizing platelet-rich plasma in combination with freeze-dried bone allograft: case series. J Periodontol 2000;71:1654-61. Crossret

11. Nash TJ, Howlett CR, Martin C, Steele J, Johnson KA, Hicklin DJ. Effect of platelet-derived growth factor on tibial osteotomies in rabbits. Bone 1994;15:203-8.

12. Robiony M, Polini F, Costa F, Politi M. Osteogenesis distraction and platelet-rich plasma for bone restoration of the severely atrophic mandible: preliminary results. J Oral Maxillofac Surg 2002;60:630-5. Crossre]

13. Rodriguez A, Anastassov GE, Lee H, Buchbinder D, Wettan H. Maxillary sinus augmentation with deproteinated bovine bone and platelet rich plasma with simultaneous insertion of endosseous implants. J Oral Maxillofac Surg 2003;61:157-63. Crossre

14. Schlegel KA, Donath K, Rupprecht S, Falk S, Zimmermann R, Felszeghy $\mathrm{E}$, et al. De novo bone formation using bovine collagen and plateletrich plasma. Biomaterials 2004;25:5387-93. Crossret

15. Anitua E, Andia I, Ardanza B, Nurden P, Nurden AT. Autologous platelets as a source of proteins for healing and tissue regeneration. Thromb Haemost 2004;91:4-15.

16. Novicoff WM, Manaswi A, Hogan MV, Brubaker SM, Mihalko WM, Saleh KJ. Critical analysis of the evidence for current technologies in bone-healing and repair.J Bone Joint Surg Am 2008;90 Suppl 1:85-91.

17. Pape HC, Evans A, Kobbe P. Autologous bone graft: properties and techniques. J Orthop Trauma 2010;24 Suppl 1:36-40. Crossre

18. Marx RE, Carlson ER, Eichstaedt RM, Schimmele SR, Strauss JE, Georgeff KR. Platelet-rich plasma: Growth factor enhancement for bone grafts. Oral Surg Oral Med Oral Pathol Oral Radiol Endod 1998;85:638-46. Crossret

19. Anitua E, Sánchez M, Orive G, Andía I. Shedding light in the controversial terminology for platelet rich products. J Biomed Mater Res A 2009;90:1262-3. Crossret

20. Dohan Ehrenfest DM, Bielecki T, Del Corso M, Inchingolo F, Sammartino G. Shedding light in the controversial terminology for platelet-rich products: platelet-rich plasma (PRP), platelet-rich fibrin (PRF), plateletleukocyte gel (PLG), preparation rich in growth factors (PRGF), classification and commercialism. Biomed Mater Res A 2010;95:1280-2

21. Mora R, Pedrotti L, Battista Galli G. Failure of Union. Nonunion of the long bones: diagnosis and treatment with compression: distraction techniques. Springer, Italy 2006.

22. Marsell R, Einhorn TA. Emerging bone healing therapies. J Orthop Trauma 2010;24 Suppl 1:4-8. Crossret

23. Urist MR, Silverman BF, Büring K, Dubuc FL, Rosenberg JM. The bone induction principle. Clin Orthop Relat Res 1967;53:243-83. Crossre.

24. Jones CB. Biological basis of fracture healing. J Orthop Trauma 2005;19(10 Suppl):1-3. Crossre

25. Wixson SK, Smiler KL Anesthesia and analgesia in rodents. In: Kohn DF, Wixson SK, White WJ, Benson GJ (eds) Anesthesia and analgesia in laboratory animals. Academic, San Diego 1998. p. 173-84.

26. Alper G, Bernick S, Yazdi M, Nimni ME. Osteogenesis in bone defects in rats: the effects of hydroxyapatite and demineralized bone matrix. Am J Med Sci 1989;298:371-6. Crossret

27. Ozturk AM, Cila E, Kanatli U, Isik I, Senkoylu A, Uzunok D, et al. Treatment of segmental bone defects in rats by the stimulation of bone marrow osteo-progenitor cells with prostaglandin E2 Int Orthop 2005;29:73-7.

28. Oztürk A, Yetkin H, Memis L, Cila E, Bolukbasi S, Gemalmaz C. Demineralized bone matrix and hydroxyapatite/tri-calcium phosphate mixture for bone healing in rats. Int Orthop 2006;30:147-52. Crossret

29. Parizi AM, Oryan A, Shafiei-Sarvestani Z, Bigham AS. Human platelet rich plasma plus Persian Gulf coral effects on experimental bone healing in rabbit model: radiological, histological, macroscopical and biomechanical evaluation. J Mater Sci Mater Med 2012;23:473-83. Crossret

30. Özdemir B, Kurtiş B, Tüter G, Sengüven B, Tokman B, Pınar-Özdemir $\mathrm{S}$, et al. Double-application of platelet-rich plasma on bone healing in rabbits. Med Oral Patol Oral Cir Bucal 2012;17:171-7. Crossret

31. Lekovic V, Camargo PM, Weinlaender M, Vasilic N, Kenney EB. Comparison of platelet-rich plasma, bovine porous bone mineral, and guided tissue regeneration versus platelet-rich plasma and bovine porous bone mineral in the treatment of intrabony defects: a reentry study. J Periodontol 2002;73:198-205. Crossre

32. Camargo PM, Lekovic V, Weinlaender M, Vasilic N, Madzarevic M, Kenney EB. Platelet-rich plasma and bovine porous bone mineral combined with guided tissue regeneration in the treatment of intrabony defects in humans. J Periodontal Res 2002;37:300-6. Crossre

33. Cook SD, Baffes GC, Wolfe MW, Sampath TK, Rueger DC. Recombinant human bone morphogenetic protein-7 induces healing in a canine long-bone segmental defect model. Clin Orthop Relat Res 1994;301:302-12. Crossre

34. Gruber HE, Stasky AA. Histologic study in orthopaedic animal research. In: An YH, Friedman RJ (eds) Animal models in orthopaedic research. CRC Press, Boca Raton, 1999. p. 115-37.

35. Salkeld SL, Patron LP, Barrack RL, Cook SD. The effect of osteogenic protein-1 on the healing of segmental bone defects treated with autograft or allograft bone. J Bone Joint Surg Am 2001;83:803-16. Crossre 
36. Boden SD. Bioactive factors for bone tissue engineering. Clin Orthop Relat Res 1999;(367 Suppl):84-94. Crossre.

37. Khan SN, Bostrom MP, Lane JM. Bone growth factors. Orthop Clin North Am 2000;31:375-88. Crossret

38. Mathes SJ: Repair and grafting of bone. In: Plastic surgery. 2nd ed. Saundes Elsevier Inc, Philadelphia 2006;639-718.

39. Malhotra A, Pelletier MH, Yu Y, Walsh WR. Can platelet-rich plasma (PRP) improve bone healing? A comparison between the theory and experimental outcomes. Arch Orthop Trauma Surg 2013;133:153-65.

40. Thor A, Franke-Stenport V, Johansson CB, Rasmusson L. Early bone formation in human bone grafts treated with platelet-rich plasma: preliminary histomorphometric results. Int J Oral Maxillofac Surg 2007;36:1164-71. Crossre]

41. Castro FP Jr. Role of activated growth factors in lumbar spinal fusions. J Spinal Disord Tech 2004;17:380-4. Crossre

42. Siebrecht MA, De Rooij PP, Arm DM, Olsson ML, Aspenberg P. Platelet concentrate increases bone ingrowth into porous hydroxyapatite. Orthopedics 2002;25:169-72.

43. Butterfield KJ, Bennett J, Gronowicz G, Adams D. Effect of platelet-rich plasma with autogenous bone graft for maxillary sinus augmentation in a rabbit model. J Oral Maxillofac Surg 2005;63:370-6. Crossree

44. Kevy SV, Jacobson MS. Comparison of methods for point of care preparation of autologous platelet gel.J Extra Corpor Technol 2004;36:28-35.

45. Nagata MJ, Melo LG, Messora MR, Bomfim SR, Fucini SE, Garcia VG, et al. Effect of platelet-rich plasma on bone healing of autogenous bone grafts in critical-size defects. J Clin Periodontol 2009;36:775-83. Crossre.

46. Cheng X, Lei D, Mao T, Yang S, Chen F, Wu W. Repair of critical bone defects with injectable platelet rich plasma/bone marrow-derived stromal cells composite: experimental study in rabbits Ulus Travma Acil Cerrahi Derg 2008;14:87-95.

47. Gumieiro EH, Abrahão M, Jahn RS, Segretto H, Alves MT, Nannmark $\mathrm{U}$, et al. Platelet-rich plasma in bone repair of irradiated tibiae of Wistar rats. Acta Cir Bras 2010;25:257-63.

48. Ranly DM, McMillan J, Keller T, Lohmann CH, Meunch T, Cochran DL, et al. Platelet-derived growth factor inhibits demineralized bone matrix-induced intramuscular cartilage and bone formation. A study of immunocompromised mice J Bone Joint Surg Am. 2005;87:2052-64

49. Han B, Woodell-May J, Ponticiello M, Yang Z, Nimni M. The effect of thrombin activation of platelet-rich plasma on demineralized bone matrix osteoinductivity. J Bone Joint Surg Am 2009;91:1459-70. Crossree

50. Ranly DM, Lohmann CH, Andreacchio D, Boyan BD, Schwartz Z. Platelet-rich plasma inhibits demineralized bone matrix-induced bone formation in nude mice. J Bone Joint Surg Am 2007;89:139-47. Crossre]

51. Burhoe SO. Blood Groups of the Rat (Rattus Norvegicus) and Their Inheritance. Proc Natl Acad Sci U S A 1947;33:102-9. Crossre.

52. Moore DM. Hematology of rat (Rattus norvegicus). In: Feldman BF, Zinkl JG, Jain NC, editors. Schalm's Veterinary Hematology. Lippincott Williams\&Wilkins; 2000, p. 1210.

\section{DENEYSEL ÇALIŞMA - ÖZET}

\section{Sıçan segmenter kemik defekti modelinde trombositten zenginleştirilmiş plazmanın ve demineralize kemik matriksinin kırık iyileşmesi üzerine etkisinin karşılaştırılması}

\section{Dr. Egemen Turhan, ${ }^{1}$ Dr. Mustafa Kemal Akça, ${ }^{2}$ Dr. Ahmet Bayar, ${ }^{3}$ Dr. Murat Songür, ${ }^{3}$ Dr. Selçuk Keser, ${ }^{3}$ Dr. Mahmut Nedim Doral ${ }^{1}$}

${ }^{1}$ Hacettepe Üniversitesi Tıp Fakültesi, Ortopedi ve Travmatoloji Anabilim Dalı, Ankara

${ }^{2}$ Bandırma Devlet Hastanesi, Ortopedi ve Travmatoloji Kliniği, Balıkesir

${ }^{3}$ Bülent Ecevit Üniversitesi Tıp Fakültesi, Ortopedi ve Travmatoloji Anabilim Dalı, Zonguldak

AMAÇ: Kırık iyileşmesinin gecikmesi ortopedi ve travmatoloji kliniğinin başlıca sorunlarından biridir ve özellikle defektif kemiklerde iyileşme gecikmesi veya kaynamama görülmektedir. Bu çalışmamızda defektif kemik dokunun iyileşmesinde ticari bir ürün olan ve klinik pratikte greft olarak sıkça kullanılan demineralize kemik matriks (DBM) ve kandan üretilen ve birçok büyüme faktörü içeren trombositten zengin plazmanın (TZP) defektif kırık modelinde kırık iyileşmesi üzerine etkileri incelendi.

GEREÇ VE YÖNTEM: Kırk sekiz adet Albino-Wistar tipi sıçan I2'li gruplar halinde dört gruba ayrıldı ve sağ önkollarında dorsal insizyon ile radiuslarına ulaşılarak radiuslarında diafizden kemik çapının iki katı kadar defektif kemik modeli oluşturuldu. Dört adet sıçan ise işlem öncesi sakrifıye edilerek intrakardiak kanları alındı ve uygun santrifüj işlemleri sonrasında TZP hazırlandı. İlk grup kontrol grubu olarak ayrıldı ve kostatom ile oluşturulan kemik defekti olduğu gibi bırakılarak primer kapatıldı. İkinci grupta defekt alanı TZP ile greftlendi ve primer kapatıldı. Üçüncü grupta defektif alan TZP+DKM kombinasyonu ile greftlenirken son grupta defekt alanı DKM ile greftlendi ve primer kapatılı. İşlem sonrası onuncu haftada sıçanlar yüksek doz anestezik madde ile sakrifiye edilerek sağ önkolları diseke edildi, defekt alanı radyolojik ve histopatolojik parametreler ile incelendi. BULGULAR: Radyolojik olarak incelendiğinde TZP grubunda ve daha sonrada DKM grubunda kemikleşmenin daha iyi olduğu gözlendi. Histopatolojik inceleme sonucunda ise kaynama kalitesi açısından kontrol grubuna göre diğer grupların iyi olduğu fakat TZP grubunda kaynama kalitesinin diğer çalışma gruplarına göre daha iyi olduğu görüldü. Korteks gelişimi ve yeniden şekillenme açısından incelendiğinde TZP grunbunda sonuçların daha iyi olduğu ve yeni kemik oluşumu açısından değerlendirildiğinde ise de TZP, TZP-DKM ve DKM gruplarının kontrol grubuna göre daha iyi olduğu gözlendi.

TARTIŞMA: Çalışmamız TZP'nin defektif kemik iyileşmesi üzerine olumlu etkilerini gösteren in vitro şartlarda yapılmış bir hayvan deneyidir. Bu bulgular eşliğinde değerlendirldiğinde defektif kemik iyileşmesinde TZP ve DKM'nin etkisinin aynı olduğu fakat birlikte kullanımında birbirlerinin etkilerini arttırmadığı kanaatine varılmıştır. Trombositten zengin plazmanın otolog kandan ve ameliyathane şartlarında dahi üretebiliyor olması, ek bir maliyet ve ek morbiditeye neden olmaması nedeniyle ticari bir ürün olan DKM'nin bir alternatifi olabileceğini düşünmekteyiz.

Anahtar sözcükler: Demineralize kemik matriks, lazma, segmenter kemik defekti; trombosit.

Ulus Travma Acil Cerrahi Derg 2017;23(2):91-99 doi: 10.5505/tjtes.2016.68249 